REVIEWS

\title{
Protein kinase ASK1 as potential therapeutic target
}

\author{
G. P. Volynets, V. G. Bdzhola, O. P. Kukharenko, O. V. Sovetova, S. M. Yarmoluk
}

Institute of Molecular Biology and Genetics, NAS of Ukraine

150 Academician Zabolotny Str., Kyiv 03680 Ukraine

volinetc_galina@mail.ru

\begin{abstract}
Apoptosis signal-regulating kinase 1 (ASK1) is serine/threonine kinase of kinase 5 that activates MAP-kinase (MAPKKK5). ASK1 induces apoptosis via the JNK and 38 signaling pathways. This review is focused on three main characteristics of ASK1: the structure, the regulatory mechanisms of kinase activity and the physiological role. ASK1 is required for apoptosis induced by oxidative stress, TNF- $\alpha, F a s$ and endoplasmic reticulum. It also regulates differentiation and death of neurons. ASK1 has been shown to be required for the innate immune response. This kinase is a critical signaling molecule for cardiac hypertrophy and remodeling. ASK1 also accelerates endothelial cell senescence in diabetic patients. Inhibition of the ASK1-p38 pathway could be useful for preventing vascular ageing and treatment of neurodegenerative and cardiac diseases.
\end{abstract}

Keywords: ASK1, apoptosis, differentiation, immune response, cardiac hypertrophy.

Introduction. Apoptosis is a highly regulated process of programmed cell death that is of great importance for normal development and homeostasis of multicellular organisms. The disorders in apoptosis regulation can lead to cancer, autoimmune and neurodegenerative diseases. Therefore, the investigation of regulatory mechanisms of programmed cell death is a fundamental task of cell biology.

The capability of cells to react most adequately against different changes of external and internal environment is based on the interaction of intracellular signaling pathways. Their integration is essential for

(C) Institute of Molecular Biology and Genetics NAS of Ukraine, 2009 the regulation of such physiological processes as proliferation, differentiation and apoptosis [1]. Mitogen-activated protein kinase signaling pathways (MAPK) are currently believed to play a decisive role in apoptosis regulation. MAP kinase pathways are well-conserved in evolution from yeast to human and regulate death and survival in all eukaryotic cells. An important intermediate of MAPK signaling cascades is ASK1 (Apoptosis signal-regulating kinase 1) that activates both $\mathrm{JNK}$ (c- $\underline{\mathrm{J} u n} \underline{\mathrm{NH}}_{2}$-terminal kinase) and p38 pathways in response to inflammatory cytokines (TNF- $\alpha$ and interleukin-1) and external stress stimuli, including UV-irradiation and reactive oxygen species (ROS) [2]. The phosphorylation of p38 MAPK and JNK leads to the activation of corresponding chains of 


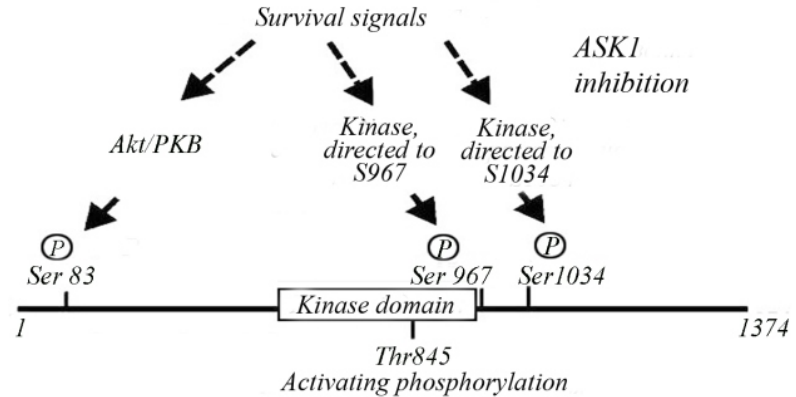

Fig.1 Schematic model of the regulation of ASK1 activity by phosphorylation. ASK1 is activated via autophosphorylation of Thr845 at the activation loop. Phosphorylation of Ser83, Ser967, and Ser1034 results in the decrease in ASK1 activity and negatively controls the kinase proapoptotic activity.

reactions, which can modify the expression of genes, involved in cell proliferation, differentiation, and apoptosis [3]. Current data concerning the structure of ASK1, regulatory mechanisms of the kinase activity and physiological role are analyzed in the review.

The structure of ASK1. Apoptosis signal-regulating kinase $\underline{1}$ (ASK1) is a serine/threonine mitogen-activated protein kinase kinase kinase 5 (MAPKKK5), present in all eukaryotic organisms. ASK1 is a protein with molecular weight of $170 \mathrm{kDa}$, ASK1 gene map locus 6q22.33. Human and mouse ASK1 consists of 1374 and 1380 amino acids respectively, and has 11 kinase subdomains. Coiled-coil domains are located in $\mathrm{N}$ - and C-termini. C-terminus of the molecule is necessary for the formation of signalosome and self-activation of the kinase. N-terminus act as a centre of protein-protein interactions. The middle part of the molecule contains the catalytic domain which displays a typical protein kinase fold, comprising the five $\beta$ sheets and helix $\alpha \mathrm{C}$, constituting a small lobe (residues 670-757) and a large mainly alpha helical C-terminal lobe subdomain(residues 761-940) [4, 5].

The regulation of ASK1 activity. ASK1 activation triggers various biological responses such as differentiation, senescence, inflammation and apoptosis, depending on cell type and cellular context. The important physiological role of ASK1 makes it necessary to study the regulatory mechanisms of its kinase activity. Three main regulatory mechanisms are known, namely, phosphorylation, oligomerization and protein-protein interactions. Autophosphorylation of Thr845 in the activation loop is required for ASK1 activation. The modulation of activity is also performed by other kinases, that phosphorylate three amino acid residues of ASK1. Phosphorylation of Ser83, Ser967 or Ser1034 causes the decrease in ASK1 activity and negatively controls its proapoptotic action (Fig. 1) [5-7].

It was demonstrated that intramolecular interaction between $\mathrm{N}$ - and $\mathrm{C}$ - termini domains of ASK1 results in the formation of inactive form, while homooligomerization of the kinase correlates with its activation [4]. The interaction between ASK1 monomers is based primarily on the surfaces complementarity - N-terminus domain of one molecule interacts with $\mathrm{C}$-terminus of the other. The interaction between the molecules involves a number of direct hydrogen bonds (Leu700-Asn776', Asn702-Tyr783', Gln703-Thr779', and Arg705-Thr813' [and vice versa]), as well as water-mediated hydrogen bonds (Gln756-HOH-Tyr814') (the apostrophe denotes the symmetry equivalent molecule. In addition, multilayer $\pi$-stacking and hydrophobic interactions Arg705-Tyr814'-Pro758/Pro758'-Tyr814-Arg705' may also contribute to the dimerization [5].

Protein-protein interactions are of the greatest importance in the regulation of ASK1 activity. In response to the signals of TNF- $\alpha$ and Fas, ASK1 binds to TRAF2 (TNF receptor-associated factor $\underline{2}$ ) and Daxx protein, respectively, which ensures functional activation of ASK1. This triggers cell apoptosis via activation of JNK-dependent signaling pathway [8,9].

Proapoptotic activity of ASK1 is inhibited by many other proteins. There are its partners-antagonists in the cell: thioredoxin (Trx) [10], glutaredoxin (Grx) [11], 14-3-3 proteins [12], CHIP (--terminus of Hsp70-interacting protein) [13], SUMO-1 (ㅁmall ubiquitin-related modifier-1) [14], mGSTM1-1 (mouse

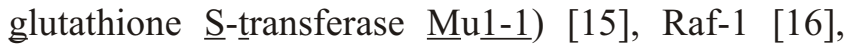
phosphatase Cdc25A ( Cell division cycle 25 homolog A (Schizosaccharomyces pombe)) [17] etc.

The interaction between Trx and ASK1 was found to depend on the redox status of Trx and this binding was observed only under reducing conditions. Apoptotic stimuli such as TNF- $\alpha$ and ROS activate ASK1 in part by oxidizing Trx and releasing it from ASK1, resulting in the activation of ASK1 through 
oligomerization and phosphorylation [18]. There are current experimental data on redox-independent inhibition of ASK1 by thioredoxin. In the case of overexpression Trx promotes ASK1 ubiquitination and degradation in bovine aorta endothelial cells, and this activity of Trx is dependent on its binding to ASK1 [19].

GRX protein binds to the C-terminus of ASK1 depending on the redox state of GRX as well. This interaction inhibits ASK1-mediated apoptosis, while overexpression of Grx was found to protect cells from glucose deprivation-induced death [11].

14-3-3 proteins are a large family of adapter phosphoserine/phosphothreonine-binding molecules [20]. There are several known mechanisms of their inhibiting ASK1-mediated apoptosis. The interaction of 14-3-3 with ASK1 may inhibit the ability of ASK1 to activate $\mathrm{JNK}$ and $\mathrm{p} 38$ pathways or other potential effectors directly involved in apoptosis. The binding of 14-3-3 proteins to ASK1 depends on phosphorylation of Ser967 i.e. its dephosphorylation correlates with the dissociation of these proteins, and the mutation of this residue blocks their interaction [21]. Alternatively, 14-3-3 may determine the localization of ASK1 in cells, sequestering it in a compartment distinct from ASK1's death effectors [12]. These data indicate that 14-3-3 proteins regulate ASK1 function, controlling its subcellular distribution.

Another way of ASK1 regulation is through inhibition by cytosolic chaperones of Hsp 70 family. CHIP (C-terminus of $\underline{H}$ sp70-interacting protein) is a co-chaperone and ubiquitin ligase that interacts with Hsp70 through an amino-terminal tetratricopeptide repeating (TPR) domain. Since ASK1 contains an acceptor site to this domain, a role of CHIP in regulating ASK1 function was examined. CHIP interacted with ASK1 and induced its ubiquitination and proteasome-dependent degradation [13]. Raf-1, a negative regulator of ASK1, induces the formation of inactive conformation of the kinase through the interaction with the N-terminal domain of ASK1. It is possible that Raf-1 binding interferes with the interaction of ASK1 with its effectors such as MKK3 or regulators such as Daxx. There is another opinion on the inhibitor function of Raf-1. It has been reported that Raf-1 is associated with Akt, which phosphorylates and negatively regulates ASK1 [22].

SUMO-1 and mGSTM1-1 demonstrate negative regulatory influence on ASK1 activity via protein-protein interaction, but not through enzymatic activity $[14,15]$.

There are also some known phosphatases, capable of interacting with ASK1. CDC25 inhibits ASK1 due to association without any enzymatic activity. The overexpression of CDC25A diminishes homo-oligomerization of ASK1 [17], required for its activation [4]. PP5 (Protein phosphatase $\underline{5}$ ) dephosphorylates Thr845 in the activation loop of ASK1 and inhibits $\mathrm{H}_{2} \mathrm{O}_{2}$-induced activation of ASK1 [23]. SKRP1 ( Stress-activated protein kinase pathway-regulating phosphatase 1) promotes ASK1 association with its substrate MKK7, but inhibits JNK-dependent signaling. Only the phosphatase, responsible for ASK1 dephosphorylation at pSer967, has been implicated in positive regulation of ASK1 activity [24].

Therefore, the activity of ASK 1 is controlled by different molecular mechanisms at multiple levels. However, the complete picture of the ASK1 regulation in the cellular signaling network is not yet revealed.

ASK1 may be activated by different proapoptotic stimuli, including oxidants, death receptors, endoplasmic reticulum (ER) stress, caused by the accumulation of unfolded proteins in the ER lumen, etc.

ASK1 compartmentalization is critical for responses to various proapoptotic stimuli. Cytoplasm-located ASK1 mediates Fas or ER stress-induced extrinsic apoptotic pathway. In contrast, ASK1 located in mitochondria triggers cell death via an intrinsic apoptotic pathway in response to TNF, ROS, or DNA damaging agents [25].

The role of ASK1 in signaling induced by oxidative stress. ROS are thought to participate in a wide variety of cellular functions, including cell proliferation, differentiation and apoptosis. ROS are either formed via different processes in the cell or are of exogenous origin. Uncontrolled formation of ROS may result in disorders of the structure and function of such cellular components as DNA, proteins and lipids, which, in its turn, leads to oxidative stress. The latter is 

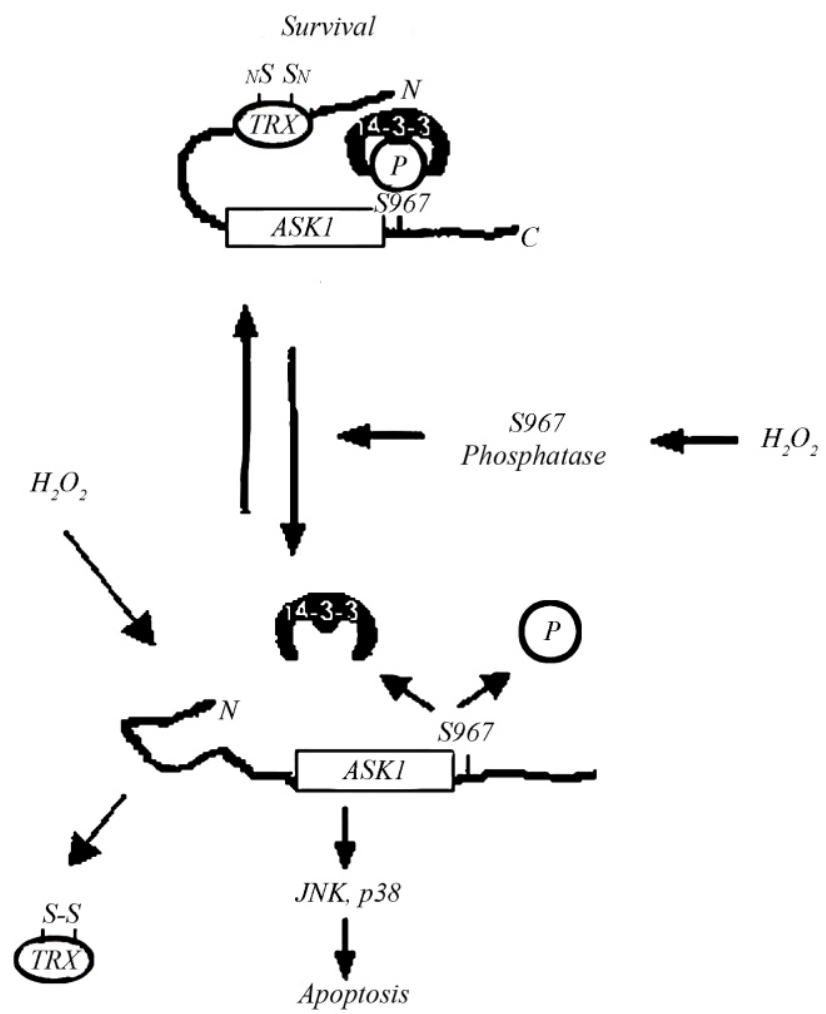

Fig.2 The regulatory mechanism of ASK1 activity in response to oxidative stress. $\mathrm{H}_{2} \mathrm{O}_{2}$ induces the dissociation of Trx from N-terminus of ASK1 and stimulates the phosphatase directed to pSer967 ASK1. The dephosphorylation by this residue results in the dissociation of 14-3-3 proteins, activation of ASK1, its effector kinases, and triggering of apoptosis.

involved in many diseases, such as atherosclerosis, diabetes, arthritis, cancer and neurodegenerative processes [26]. The investigation of intracellular signaling pathways, regulating the response to the stress caused by oxidants, is important for drug development.

The recent investigations have demonstrated that ASK1 plays a critical role in the cell response to the $\mathrm{H}_{2} \mathrm{O}_{2}$-induced stress. Mouse embryonic fibroblasts derived from ASK1-deficient mice were resistant to $\mathrm{H}_{2} \mathrm{O}_{2}$-induced apoptosis [27]. One of the mechanisms, mediating the impact of $\mathrm{H}_{2} \mathrm{O}_{2}$ on the cell, is dissociation of Trx from ASK1 [18]. $\mathrm{H}_{2} \mathrm{O}_{2}$ also controls the phosphorylation status of ASK1 by Ser967. The activity of hydrogen peroxide is necessary to stimulate the phosphatase, catalysing ASK1 dephosphorylation by this amino acid residue, with subsequent dissociation of 14-3-3 proteins, the activation of ASK1 and its effector kinases (Fig. 2) [27]. The phosphorylation of Ser967 and the association with 14-3-3 proteins has an influence on the interaction of ASK1 with its intracellular inhibitors - Trx and Grx. The dephosphorylation of pSer967 diminishes the affinity of ASK1 to these proteins, therefore reducing kinase sensitivity to $\mathrm{H}_{2} \mathrm{O}_{2}$ [28]. Thus, the induction of ASK1-mediated response of cells to the stress is likely to take place via the activation of the specific phosphatase, modulating pSer967-dependent interaction of ASK1 with 14-3-3 proteins and thioredoxin. These data establish a close link between signaling, dependent on ROS, and enzyme network that converges on Ser-967 of ASK1.

There are remarkable results confirming the other kinases involvment in the modulation of ASK1 activity. In the endothelial cells $\mathrm{H}_{2} \mathrm{O}_{2}$ induces the phosphorylation of $\mathrm{PKD}$ and its translocation from the membrane to cytoplasm where it associates with ASK1. This type of association is mediated by plextrin-homology $(\mathrm{PH})$ domain $\mathrm{PKD}$ and C-terminus of ASK1. The inhibition of PKD by staurosporine or siRNA blocks $\mathrm{H}_{2} \mathrm{O}_{2}$-induced activation of endothelial cells apoptosis [29]. On the contrary, Akt-kinase is capable of efficient inhibiting the response of ASK1 to the oxidative stress due to the phosphorylation of Ser83 [6]. Therefore, the current data testify to the presence of very complicated mechanisms of regulating ASK1 activity in the cellular response to the oxidative stress.

The role of ASK1 in the Fas-induced cell death. Fas belongs to the family of membrane proteins that transduce apoptotic signals. Upon Fas activation the proapoptotic protein Daxx binds to the $\mathrm{N}$-terminus of ASK1 in a ligand-dependent manner and activates JNK, which may sensitize cells to apoptosis (Fig. 3) [30].

It was proposed that during Fas-induced apoptosis ASK1 activation is regulated by HIPK1 ( Homeodomain-interacting protein kinase-1), which is localised in the nucleus and regulates the activity of a wide range of transcription factors. Upon Fas activation HIPK1 translocates to cytoplasm and associates with the signaling AIP-ASK1 complex and promotes the dissociation of Trx and 14-3-3 proteins. The mechanism of this dissociation is yet to be determined. It is likely to be promoted by the activation 

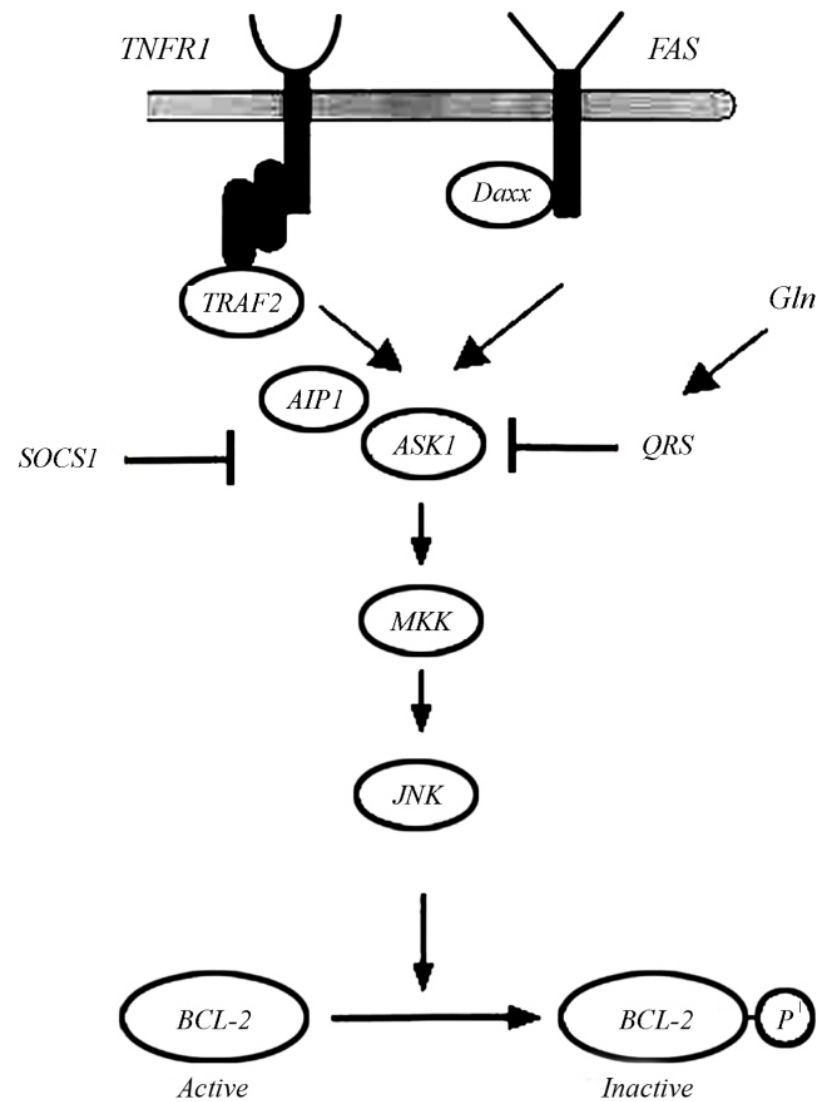

Fig. 3 The theoretical model of TNF- and Fas-dependent activation of ASK1. The activation of TNFR1 causes the dissociation of AIP1-TNFR1 complex with subsequent diffusion of AIP1 into the cytoplasm, where it interacts with ASK1 and changes its conformation. This promotes the association of ASK1 with TRAF2 and induces JNK-signaling pathway which results in phosphorylation of anti-apoptotic protein Bcl-2 and its inactivation. Upon Fas induction the Daxx protein binds to N-terminus of ASK1, changing autoinhibiting intramolecular interaction between $\mathrm{N}$ - and $\mathrm{C}$-termini of the kinase for formating active conformation. The activated kinase triggers JNK-dependent apoptosis. Negative regulators of ASK1 are SOCS1 and glutamyl-tRNA synthetase (QRS), the effect of which is positively controlled by the cellular concentration of Gln.

of the phosphatase responsible for the dephosphorylation of pSer967 [31].

A negative ASK1 modulator - glutamyl-tRNA synthetase (QRS) inhibits Fas-induced cell death. The antiapoptotic interaction of QRS with ASK1 is positively controlled by the cellular concentration of Gln [32].

ASK1 in TNF-induced apoptosis. ASK1 is a mediator of TNF- $\alpha$-induced apoptosis. One of the main physiological targets of TNF- $\alpha$ action are vascular endothelial cells [33]. The cytokines belonging to
TNF-family interact with TNFR (TNF receptor). TNF signaling is negatively regulated by the binding of TNFR intracytoplasmic domain to the protein called

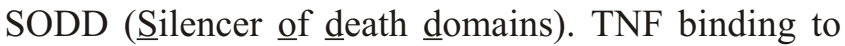
TNFR releases SODD with subsequent recruiting of TRADD (TNF receptor-associated death-domain protein), which functions as a platform adaptor to recruit both RIP1 (Ser/Thr protein kinase receptor-interacting protein 1) and TRAF2 (TNFR-associated factor- $\underline{2}$ ) assembling a multiprotein complex that activates downstream signaling pathways [34]. TRAF2 directly interacts to C-terminal domain of ASK1 and promotes the oligomerization of ASK1, preventing its autophosphorylation by Thr845 [35].

Protein AIP1 (ㅅSK1-interacting protein $\underline{1}$ ) plays an important regulatory role in the formation of TRAF2-ASK1 complex. AIP1 belongs to the Ras-GAP family (the protein, activating GTPase activity of Ras) and localized mainly on the cytoplasmatic side of the membrane in the complex with TNFR1. In response to TNF binding AIP1 dissociates from TNFR1 with concomitant diffusion of AIP1 into the cytoplasm where it associates with TRAF2 and ASK1. Thus, it is the mechanism of positive regulation of ASK1-JNK signaling pathway, resulting in the phosphorylation and inactivation of antiapoptotic protein Bcl-2 (Fig. 3) [36].

TNF- $\alpha$ induces the dissociation of Trx from ASK1 by generating intracellular reactive oxygen species to oxidize Trx. ASK1 in cytoplasm mediates a JNK-dependent apoptotic pathway associated with JNK activation, Bid cleavage, and Bax translocation. ASK1 in mitochondria mediates a JNK-independent apoptotic pathway, the mechanism of which is not understood. Nevertheless, both pathways cause the release of cytochrom $\mathrm{C}$ and activation of caspase 3 [37].

Another interacting partner of ASK1 is SOCS1 (Suppressor of cytokine signaling $\underline{1}$ ), that forms a labile complex with ASK1. The phosphotyrosine-binding $\mathrm{SH} 2$ domain of SOCS1 is critical for its association with ASK1. pTyr718 of ASK1 plays a key role in the process of binding to SOCS1. The mutation at this amino acid diminished the binding ASK1 to SOCS1. TNF- $\alpha$ may induce the dissociation of ASK1-SOCS1 complex [38]. 
ASK1 is required for endoplasmic reticulum (ER) stress-induced apoptosis. ER stress is induced by accumulation of unfolded or misfolded proteins within the endoplasmic reticulum lumen. ER stress has been implicated in neurodegenerative processes such as Alzheimer's disease, Parkinson's disease, polyglutamine diseases, etc. The cells are trying to adapt to endoplasmic reticulum stress through the activation of stress-induced protein kinase pathways. Initial mediators of ER responses are IRE1 (Inositol-requiring enzyme 1), ATF6 (ㅅctivating transcription factor $\underline{6}$ ), OASIS (미 a astrocyte specifically induced substance), etc. [39]. These transmembrane proteins modulate transport of newly synthesized proteins into the ER. If this adaptation is insufficient to avoid stress, the cells undergo apoptosis. A number of works indicate that ASK1 plays essential roles in the regulation of apoptosis, induced by ER stress. During neuronal cell death ASK1 interacts with TRAF2 and is recruited by IRE1 which is a transmembrane sensor of endoplasmic reticulum. The formation of IRE1-TRAF2-ASK1 complex promotes the activation of JNK-dependent apoptosis [40]. In the neurons derived from ASK1 deficient mice activation of endogenous JNK was almost completely eliminated [41]. These data demonstrate the important role of ASK1 in ER stress.

The participation of ASK1 in neuronal differentiation and apoptosis. Besides the significant role of ASK1 in the pathways of signal transmission of apoptosis, induced by different factors, it is also important for the differentiation of cells [42].

ASK1 takes part in the differentiation of neurons and inhibition of gliogenesis through p38 MAP kinase activation. $\mathrm{Ca}^{2+}$ influx evoked by membrane depolarization in neurons induces activation of $\mathrm{Ca}^{2+} /$ calmodulin-dependent protein kinase II (CAMK2), which phosphorylates ASK1. In its turn, ASK1 activates $\mathrm{p} 38$ via the phosphorylation of MKK3 or MKK6. Thus, ASK1 is a critical intermediate of $\mathrm{Ca}^{2+}$ signaling between CaMKII and p38 MAP kinase [43] ASK1 was shown to induce the expression of some neuron-specific proteins, thus promoting the neuronal differentiation of cells (PC12).

The mechanism of ASK1 participation in the inhibition of gliogenesis is yet unknown. The differentiation of stem cells in astroglial cells is determined by BMPs factors (Bone morphogenetic proteins). The response of cells to BMPs depends on the amount of endogenous neurogenin in the cell. When the levels of neurogenin are low, BMP induces astroglial fate in immature neural progenitor cells. ASK1 is likely to stimulate the synthesis of neurogenin and inhibits glial-cell differentiation [44].

ASK1 is an important molecule in the pathogenesis of neurodegenerative diseases. Alzheimer's disease is caused by the accumulation of $\beta$-amyloid $(\mathrm{A} \beta)$ derived from A $\beta \mathrm{PP}$ (ㅅmyloid precursor protein) [45]. The study using A $\beta P P$ gene knockout mice, proved this protein to perform important physiological functions in the development of the nervous system [46]. ASK1 is capable of forming a complex with A $\beta$ PP via JIP-1b (JNK signaling scaffold protein). In this complex $\mathrm{C}$-terminus of $\mathrm{A} \beta \mathrm{PP}$ binds $\mathrm{JNK}$ and promotes its activation, bringing the latter closer to ASK1 [47].

Upon the treatment cells with $A \beta$, ASK1 activates JNK signaling pathway due to the formation of reactive oxygen species, causing oxidation of Grx1 and Trx1. $A \beta$-induced neurotoxicity is efficiently inhibited by the overexpression of Grx1 or Trx1. ASK1-/- neurons were resistant to $A \beta$-induced cell death [48].

Thus, considering the role of ASK1 in the development of Alzheimer's disease, it may be regarded as a potential therapeutic target in the treatment of neurodegenerative diseases.

The role of ASK1 in hypertrophy and apoptosis of cardiomyocytes. The main mechanisms of the growth of cardiac muscle tissue are hypertrophy and hyperplasia of cardiomyocytes [49]. These processes along with programmed cell death lead to normal development and functioning of the heart.

The hypertrophy of cardiomyocytes is an important adaptive process in response to such extracellular stimuli as mechanical stress, cytokines, and growth factors. But sustained extracellular stimuli may lead to excessive cardiac remodeling and finally to heart failure.

ASK1 was identified as a novel signaling intermediate involved in cardiac myocyte hypertrophy. The overexpression of the dominant-negative mutant of ASK1 inhibits hypertrophy, while constitutively 
active ASK1 leads to hypertrophy via the activation of NF-kB [50]. The activation of ASK1 is believed to take place due to binding of GPCR agonists. The intermediate molecule, which mediates the hypertrophic signal from GPCR to ASK1, has not been identified yet. The literature data allow to suggest that GTPase Rac1 may act as such a mediator. This protein regulates the activity of NADPH-oxidase system, providing the formation of ROS which cause the dissociation of thioredoxin from ASK1 and its activation [51].

The mechanical stress can lead to an adaptive cardiac hypertrophy characterized by a normal cardiac structure and normal or enhanced work of the heart. ASK1-deficient mice showed exaggerated growth of the heart accompanied by typical characteristics of physiological hypertrophy, i.e. without any pathology. The results of these experiments indicate that ASK1/p38 signaling pathway negatively regulates physiological hypertrophy [52].

Noteworthy is the opinion of the authors [53] regarding the participation of ASK1 in the processes of cardiomyocyte death. The molecular mechanisms of the death of cardiac cells remain to be clarified. Ischemia-reperfusion in the heart of wild type mice leads to necrotic injury, whereas infarct size was drastically reduced in the mice with ASK1 knockout gene. The necrotic injury was not accompanied with any evidence of apoptosis. ASK $1^{-/}$cardiomyocytes were more resistant to apoptosis, induced by $\mathrm{H}_{2} \mathrm{O}_{2}$ or $\mathrm{Ca}^{2+}$, than normal cardiomyocytes. These data suggest that ASK1 is involved in necrosis as well as apoptosis of the heart [53].

Therefore, these date testify to possible participation of ASK1 in the development of the heart pathological processes - hypertrophy, apoptosis, and necrosis of cardiomyocytes. Thus, it may be considered as a potential therapeutic target in the treatment of cardiac diseases.

The participation of ASK1 in the immune response. During the immune response the pathogens are first recognized by the cell surface receptors. The main significance among them is attributed to TLRs (Toll-like receptors), that recognize structurally conservative molecules of a wide spectrum of microorganisms. Ligand binding induces conformational changes of receptors and subsequent activation of p38 and JNK signaling pathways.

The role of ASK1-p38 pathway in the immune response was demonstrated in the experiments using the ASK1 knockout mice. In the splenocytes and dendritic cells derived from ASK1-deficient mice LPS-induced activation of p38 MAPK was not detected and the production of inflammation cytokines - TNF, interleukin-6, and interleukin-1 $\beta$ - was also reduced. The literature data allow to suggest that the ASK1-p38 signaling pathway is required for inflammation in response to LPS. The mechanism of ASK1 activation by LPS was also predicted. LPS treatment leads to the generation of ROS; the increased ROS production induces the dissociation of Trx from ASK1, thereby enabling the recruiting TRAF6 to ASK1 to form the activated ASK1 signalosome, which promotes activation of ASK1-p38 pathway.

The study in vivo also supports the role of ASK1 in the immune response. ASK1-deficient mice were resistant to LPS-induced septic shock, while most wild-type mice after intraperitoneal injection of LPS died within $40 \mathrm{~h}$ [4]. The selective inhibitors of ASK1 would be promising reagents for the development of clinical anti-inflammatory agents to treat septic shock.

The activation of ASK1 at the high glucose level. In case of hyperglycemia the increased activity of ASK1 promotes senescence of endothelial cells. High glucose concentration induces the increase in the levels of ASK1 expression. The incubation of endothelial cells in the medium with high glucose level increased the proportion of cells expressing senescence-associated $\beta$-galactosidase (SA- $\beta$-gal), which is a known physiological marker of the senescence process. Transfection with an adenoviral construct including a dominant negative form of ASK1 gene significantly inhibited SA-beta-gal activity induced by high glucose level. Vice versa, the infection with an adenoviral construct expressing the constitutively active ASK1 gene promotes the increase in the levels of SA- $\beta$-gal activity [54].

Hyperglycemia increased mitochondrial ROS production, which results in the dissociation of thioredoxin and glutaredoxin from ASK1 and subsequent activation of JNK-dependent apoptosis (Fig.4) [55]. In cell culture, incubation of epithelial 


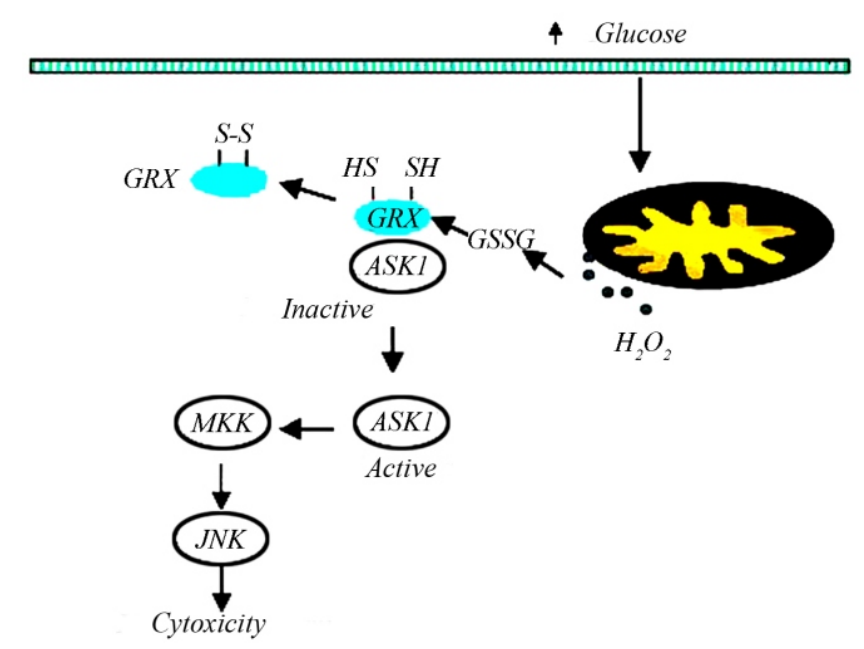

Fig.4 The activation of ASK1 with high glucose concentration. ASK1 is activated at the increase in glucose concentration due to elevated intracellular levels of $\mathrm{H}_{2} \mathrm{O}_{2}$ and oxidized glutathione which results in the dissociation of glutaredoxin and activation of JNK-dependent signaling pathway and cytotoxicity.

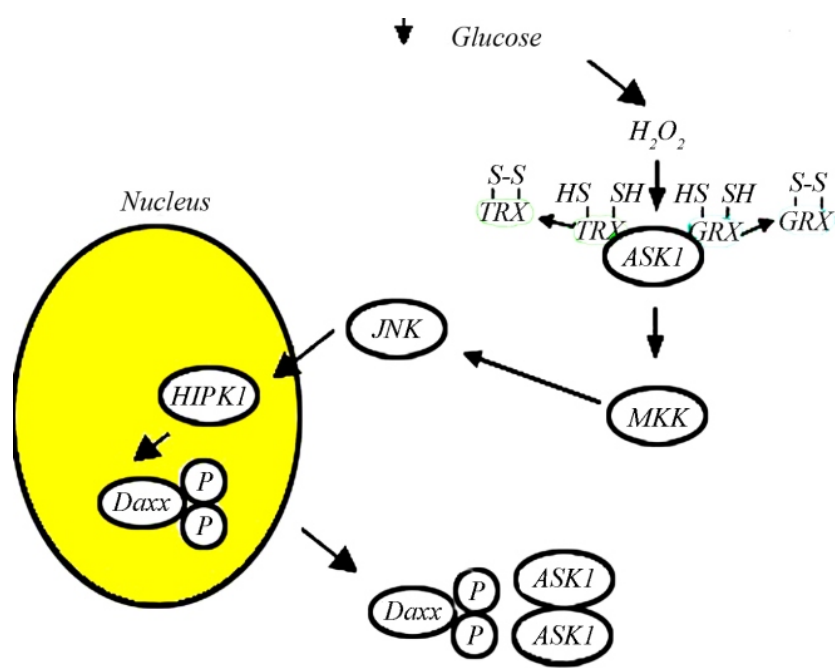

Fig.5 Schematic model of the activation of ASK1 during glucose deprivation. If the concentration of glucose in the medium drops to low levels, the intracellular amount of $\mathrm{H}_{2} \mathrm{O}_{2}$ in the human prostate adenocarcinoma DU-145 cells increases which results in the dissociation of Trx and Grx and activation of ASK1-MKK-JNK-signaling pathway. At these conditions HIPK1 is activated and phosphorylates Daxx which causes its relocalization from the nucleus to the cytoplasm. The translocated form of Daxx binds to ASK1 and promotes its oligomerization, thus functioning as a positive regulator of the activation of ASK1-MEK-MAPK transduction

cells in the medium with high glucose level, increased SLK (Ste20-like kinase) activity. SLK can induce phosphorylation of ASK1 and specifically activates the apoptosis, dependent on p38MAPK [56].

In human prostate adenocarcinoma DU-145 cells the intracellular level of $\mathrm{H}_{2} \mathrm{O}_{2}$ is elevated due to decreased glucose concentration in the medium. These conditions activate the signaling pathway ASK1-MEK-MAPK-HIPK1. Activated HIPK1 phosphorylates Daxx which results in the relocalization of Daxx from the nucleus to the cytoplasm. The translocated form of Daxx binds to ASK1 and causes its oligomerization, thus functioning as a positive regulator of activation of ASK1-MEK-MAPK transduction pathway (Fig.5) [57]. These controversial results indicate the complicated mechanisms of regulating ASK1-dependent signaling pathways which proves the necessity of carrying out further researches in this field.

ASK1 inhibitors as a potential therapeutic target. The recent investigations, aimed at the determination of ASK1 role in the functioning of the cellular signaling networks and its direct participation in the regulation of cell survival and death, revealed the connection between the increased activity of the kinase and the development of many pathologies. It is a prerequisite for the search for potential ASK1 inhibitors which may be used in the medical practice. Protein kinase ASK1 is an important proapoptotic cellular intermediator in response to the activity of ROS, Fas, TNF- $\alpha$, incorrect folding of proteins, etc. Besides regulating stress-induced signaling pathways, ASK1 performs a number of other biological functions, like modulation of cell differentiation and senescence. The kinase is involved in many pathological processes. For instance, ASK1 activation by oxidants is a key mechanism of $A \beta$-induced neurotoxicity in Alzheimer's disease. Its role in the immune response and the development of inflammation was also characterized. There are more data testifying to its participation in the cardiac hypertrophy and senescence of endothelial cells in diabetic patients.

The experiments on blocking the function of this target using different genetic, biochemical, and chemical approaches directly or indirectly - via other molecules-partners and regulatory ways, which were conducted both in vitro and in vivo bring novel evidence to the fact that symptoms and implications of the above mentioned pathologies may be diminished considerably. There is no doubt that ASK1 will position as an object of close attention for many pharmaceutical companies and will urge scientists to 
search for medical ways of influencing this protein. This search will last until clinical trials clear out the efficiency of therapeutic preparations and possible negative implications of their use.

This process has just started as only 2006-2007 allowed obtaining the most important scientific prerequisite for search at the level, corresponding to modern approaches of rational design of protein kinase inhibitors, i.e. the method of X-ray structural analysis allowed determining 3D structure of this kinase molecule. Leading biological and pharmaceutical companies, specialized in the design of protein kinase inhibitors, included ASK1 to the screening panel of chemical databases several years ago. However, there are still no official published results on any progress in the search for synthetic inhibitors of high activity and specificity to ASK1.

If one may predict possible clinical effects of the use of ASK1-specific inhibitor, i.e. its pharmacological spectrum of activity, it is reasonable to expect some trials in pathologies, which are currently related to functions of JNK-family kinases that are downstream targets of ASK1 signaling pathway. ASK1 inhibitors may also act as blockers of p38MAPK pathway, though to a smaller degree.

The preparations, directed towards the inhibition of the function of protein kinase ASK1, may act as first aid medicine in acute periods after cerebrovascular accidents and heart attacks. Their temporary use is also reasonable in the case of septic shock, local acute inflammatory processes, and toxic affection of some organs which may cause the formation of considerable zones of necrosis and destruction due to acute activation of apoptosis. The abovementioned pathologies may include toxic glomerulonephritis, hepatitis, and pancreatitis. On the contrary, acute infections, especially the ones of specific characterviral or bacterial, are likely undesired targets for blocking MAPK-signaling pathways because of possible inhibition of the immune response. Besides, long-term use of compositions, critically influencing one of the signaling pathways, which are vital for cell functioning, may have negative effect on the regulatory systems of cells.

Possible consequences of decrease in ASK1 functions include the disorder of biochemical reactions of cells at the level of reparation/remodelling systems of the tissue, blocking the cell cycle, counteraction to oxidative stresses, mutations, as well as reducting protection from transformation of some types of cells. It raises the possibility of immunodeficiency and non-specific infections. Long-term use of inhibitors of MAPK-kinase signaling pathway may sometimes result in the possibility of formation of tumours in some types of tissues. Nevertheless, the medical preparations - antagonists of MAPK-cascade, which are inhibitors of effector kinases regarding ASK1, are well under the pre-trial investigations. Therefore, ASK1 inhibitors seem to be quite reasonable therapeutic tools.

\section{Г. П. Волинець, В. Г. Бджола, О. П. Кухаренко, О. В. Совєтова, С. М. Ярмолюк}

Протеїнкіназа ASK1 як перспективна мішень для фармакологічного втручання

Резюме

Протеїнкіназа ASK1 (ㅁpoptosis signal-regulating kinase 1) - ceрин/треонінова кіназа 5 кінази МАР-кінази (МАРККК5), яка зустрічається в усіх евкаріотних організмах. ASK1 індукує апоптоз через каскади JNK i p38 у відповідь на проапоптичні стимули - активні форми оксигену, TNF- $\alpha$, Fas, стрес ендоплазматичного ретикулуму та ін. ASK1 бере участь у процесах диференціачії та загибелі нейронів. Кіназа є важливою сигнальною молекулою в гіпертрофії та апоптозі кардіоміоцитів. ASK1 залучена до розвитку імунної відповіді та до процесів старіння ендотеліальних клітин при діабеті і може бути потениійною терапевтичною мішенню для попередження старіння судин, лікування нейродегенеративних і серцевих хвороб.

Ключові слова: ASK1, апоптоз, диференціація, імунна відповідь, гіпертрофія серия.

Г. П. Волинеи, В. Г. Бджола, О. П. Кухаренко, О. В. Советова, С. М. Ярмолюк

Протеинкиназа ASK1 как перспективная фармакологическая мишень

Резюме

Протеинкиназа ASK1 (ㅁpoptosis signal-regulating kinase 1) - ceрин/треониновая киназа 5 киназы МАР-киназы (МАРККК5) обнаружена во всех эукариотных организмах. ASK1 индуиирует апоптоз посредством активации путей сигналинга JNK и p38 в ответ на проапоптические стимуль - активные формы кислорода, TNF- $\alpha$, Fas, стресс эндоплазматического ретикулума и др. ASK1 необходима в процессах дифференцииаци и гибели нейронов. Киназа участвует в развитии иммунного 
ответа и в прочессах старения эндотелиальных клеток при диабете. ASK1 является ключевой молекулой в гипертрофии и апоптозе кардиомиоцитов и может быть потенциальной терапевтической мишенью для предупреждения старения сосудов и лечения нейродегенеративных и кардиологических заболеваний.

Ключевые слова: ASK1, апоптоз, дифференцииация, иммунный ответ, гипертрофия сердия.

\section{REFERENCES}

1. Tibbles L. A., Woodgett J. R. The stress-activated protein kinase pathways // Cell Mol. Life Sci.-1999.-55, N 10.P. $1230-1254$.

2. Tobiume K., Matsuzawa A., Takahashi T., Nishitoh H., Morita K., Takeda K., Minowa O., Miyazono K., Noda T., Ichijo $H$. ASK 1 is required for sustained activations of $\mathrm{JNK} / \mathrm{p} 38$ MAP kinase and apoptosis // EMBO Rep.-2001.-2, N 3.P. 222-228.

3. Kyriakis $J$. M. Activation of the AP-1 transcription factor by inflammatory cytokines of the TNF family // Gene Exp.1999.-7, N 4-6.-P. 217-231.

4. Hayakawa T., Matsuzawa A., Noguchi T., Takeda K., Ichijo $H$. The ASK1-MAP kinase pathways in immune and stress responses // Microbes Infect.-2006.-8, N 4.-P. 1098-1107.

5. Bunkoczi G., Salah E., Filippakopoulos P., Fedorov O., Muller S., Sobott F., Parker S. A., Zhang H., Min W., Turk B. E., Knapp $S$. Structural and functional characterization of the human protein kinase ASK1 // Structure.-2007.-15, N 10.P. 1215-1226.

6. Kim A. H., Khursigara G., Sun X., Franke T. F., Chao M. V. Akt phosphorylates and negatively regulates apoptosis signal-regulating kinase $1 / /$ Mol. Cell Biol.-2001.-21, N 3.P. 893-901.

7. Fujii K., Goldman E., Park H. R., Zhang L., Chen J., Fu H. Negative control of apoptosis signal-regulating kinase 1 through phosphorylation of Ser-1034 // Oncogene.-2004.23, N 29.-P. 5099-5104.

8. Ichijo H., Nishida E., Irie K., Dijke P., Saitoh M., Moriguchi T., Takagi M., Matsumoto K., Miyazono K., Gotoh Y. Induction of apoptosis by ASK1, a mammalian MAPKKK that activates SAPK/JNK and p38 signaling pathways // Science.1997.-275, N 5296.-P. 90-99.

9. Chang H. Y., Nishitoh H., Yang X., Ichijo H., Baltimore D. Activation of apoptosis signal-regulating kinase 1 (ASK1) by the adapter protein Daxx // Science.-1998.-281, N 5384.P. 1860-1863.

10. Yamawaki H., Haendeler J., Berk B. C. Thioredoxin: a key regulator of cardiovascular homeostasis // Circ. Res.-2003.93, N 11.-P. 1029-1033.

11. Song J. J., Rhee J. G., Suntharalingam M., Walsh S. A., Spitz $D$. R., Lee Y. J. Role of glutaredoxin in metabolic oxidative stress. Glutaredoxin as a sensor of oxidative stress mediated by $\mathrm{H}_{2} \mathrm{O}_{2} / /$ J. Biol. Chem.-2002.-277, $\mathrm{N}$ 48.-P. 4656646575 .

12. Subramanian R. R., Zhang H., Wang H., Ichijo H., Miyashita $T$., $F u H$. Interaction of apoptosis signal-regulating kinase 1 with isoforms of 14-3-3 proteins // Exp. Cell Res.-2004.294, N 2.-P. 581-591.
13. Hwang J. R., Zhang C., Patterson C. C-terminus of heat shock protein 70 -interacting protein facilitates degradation of apoptosis signal-regulating kinase 1 and inhibits apoptosis signal-regulating kinase 1-dependent apoptosis // Cell Stress Chaperones.-2005.-10, N 2.-P. 147-156.

14. Lee Y. S., Jang M. S., Lee J. S., Choi E. J., Kim E. SUMO-1 represses apoptosis signal-regulating kinase 1 activation through physical interaction and not through covalent modification // EMBO Reports.-2005.-6, N 10.-P. 949-955.

15. Cho S. G., Lee Y. H., Park H. S., Ryoo K., Kang K. W., Park J., Eom S.-J., Kim M. J., Chang T. S., Choi S. Y., Shim J., Kim Y., Dong M. S., Lee M. J., Kim S. G., Ichijo H., Choi E. J. Glutathione S-transferase $\mathrm{Mu}$ modulates the stress-activated signals by suppressing apoptosis signal-regulating kinase $1 / /$ J. Biol. Chem.-2001.-276, N 16.-P. 12749-12755.

16. Chen J., Fujii K., Zhang L., Roberts T., Fu H. Raf-1 promotes cell survival by antagonizing apoptosis signal-regulating kinase 1 through a MEK-ERK independent mechanism // Proc. Nat. Acad. Sci. USA.-2001.-98, N 14.-P. 7783-7788.

17. Zou X., Tsutsui T., Ray D., Blomquist J. F., Ichijo H., Ucker D. S., Kiyokawa H. The cell cycle-regulatory CDC25A phosphatase inhibits apoptosis signal-regulating kinase $1 / / \mathrm{Mol}$. and Cell. Biol.-2001.-21, N 14.-P. 4818-4828.

18. Bishopric N. H., Webster K. A. Preventing apoptosis with thioredoxin. Ask me how // Circ. Res.-2002.-90.-P. 12371239.

19. Liu Y., Min $W$. Thioredoxin promotes ASK1 ubiquitination and degradation to inhibit ASK1-mediated apoptosis in a redox activity-independent manner // Circ. Res.-2002.-90, N 12.-P. 1259-1266.

20. Yaffe M. B. How do 14-3-3 proteins work? - Gatekeeper phosphorylation and the molecular anvil hypothesis // FEBS Lett.-2002.-513, N 1.-P. 53-57.

21. Zhang L., Chen J., Fu H. Suppression of apoptosis signalregulating kinase 1-induced cell death by 14-3-3 proteins // Proc. Nat. Acad. Sci. USA.-1999.-96, N 15.-P. 8511-8515.

22. Rommel C., Clarke B. A., Zimmermann S., Nunez L., Rossman R., Reid K., Moelling K., Yancopoulos G. D., Glass D. J. Differentiation stage-specific inhibition of the Raf-MEKERK pathway by Akt // Science.-1999.-286, N 5445.P. 1738-1741.

23. Morita K., Saitoh M., Tobiume K., Matsuura H., Enomoto S., Nishitoh $H$., Ichijo $H$. Negative feedback regulation of ASK1 by protein phosphatase 5 (PP5) in response to oxidative stress // EMBO J.-2001.-20.-P. 6028-6036.

24. Zama T., Aoki R., Kamimoto T., Inoue K., Ikeda Y., Hagiwara $M$. Scaffold role of a mitogen-activated protein kinase phosphatase, SKRP1, for the JNK signaling pathway // J. Biol. Chem.-2002.-277, N 26.-P. 23919-23926.

25. Hatai T., Matsuzawa A., Inoshita S., Mochida Y., Kuroda T., Sakamaki K., Kuida K., Yonehara S., Ichijo H., Takeda K. Execution of apoptosis signal-regulating kinase 1 (ASK1)induced apoptosis by the mitochondria-dependent caspase activation // J. Biol. Chem.-2000.-275, N 34.-P. 2657626581.

26. Martindale J. L., Holbrook N. J. Cellular response to oxidative stress: signaling for suicide and survival // J. Cell Physiol.2002.-192, N 1.-P. 1-15.

27. Matsukawa J., Matsuzawa A., Takeda K., Ichijo H. The ASK1-MAP kinase cascades in mammalian stress response // J. Biochem.-2004.-136, N 3.-P. 261-265.

28. Goldman E. H., Chen L., Fu H. Activation of apoptosis signal-regulating kinase 1 by reactive oxygen species through 
dephosphorylation at serine 967 and 14-3-3 dissociation // J. Biol. Chem.-2004.-279, N 11.-P. 10442-10449.

29. Zhang $W$., Zheng S., Storz P., Min W. Protein kinase D specifically mediates apoptosis signal-regulating kinase $1-\mathrm{JNK}$ signaling induced by $\mathrm{H}_{2} \mathrm{O}_{2}$ but not tumor necrosis factor // $\mathrm{J}$. Biol. Chem.-2005.-280, N 19.-P. 19036-19044.

30. Song J. J., Lee Y. J. Dissociation of Akt1 from its negative regulator JIP1 is mediated through the ASK1-MEK-JNK signal transduction pathway during metabolic oxidative stress: a negative feedback loop // J. Cell Biol.-2005.-170, N 1.P. 61-72.

31. Li X., Zhang R., Luo D., Park S. J., Wang Q., Kim Y., Min W. Tumor necrosis factor-induced desumoylation and cytoplasmic translocation of homeodomain-interacting protein kinase 1 are critical for apoptosis signal-regulating kinase 1-JNK/p38 activation // J. Biol. Chem.-2005.-280, N 15.P. 15061-15070.

32. Ko Y. G., Kim E. K., Kim T., Park H., Park H. S., Choi E. J., Kim S. Glutamine-dependent antiapoptotic interaction of human glutaminyl-tRNA synthetase with apoptosis signalregulating kinase 1 // J. Biol. Chem.-2001.-276, N 8.P. 6030-6036.

33. Madge L. A., Pober J. S. TNF signaling in vascular endothelial cells // Exp. Mol. Pathol.-2001.-70, N 3.-P. 317-325.

34. Jiang Y., Woronicz J. D., Liu W., Goeddel D. V. Prevention of constitutive TNF receptor 1 signaling by silencer of death domains // Science.-1999.-283, N 5401.-P. 543-546.

35. Tobiume K., Saitoh M., Ichijo H. Activation of apoptosis signal-regulating kinase 1 by the stress-induced activating phosphorylation of preformed oligomer // J. Cell Physiol.2002.-191, N 1.-P. 95-104.

36. Zhang H., Zhang R., Luo Y., D'Alessio A., Pober J. S., Min W. AIP1/DAB2IP, a novel member of the Ras-GAP family, transduces TRAF2-induced ASK1-JNK activation // J. Biol. Chem.-2004.-279, N 43.-P. 44955-44965.

37. Lim P. L. K., Liu J., Go M. L., Boelsterli U. A. The mitochondrial superoxide/thioredoxin-2/ASK1 signaling pathway is critically involved in troglitazone-induced cell injury to human hepatocytes//Toxicol. Sci.-2008.-101,N 2.-P. 341-349.

38. He Y., Zhang W., Zhang R., Zhang H., Min W. SOCS1 inhibits tumor necrosis factor-induced activation of ASK1-JNK inflammatory signaling by mediating ASK1 degradation // J. Biol. Chem.-2006.-281, N 9.-P. 5559-5566.

39. Kondo S., Saito A., Hino S., Murakami T., Ogata M., Kanemoto S., Nara S., Yamashita A., Yoshinaga K., Hara H., Imaizumi $K$. BBF2H7, a novel transmembrane bZIP trans-cription factor, is a new type of endoplasmic reticulum stress transducer // Mol. Cell Biol.-2007.-27, N 5.-P. 17161729.

40. Sekine $Y$., Takeda K., Ichijo $H$. The ASK1-MAP kinase signaling in ER stress and neurodegenerative diseases // Curr. Mol. Med.-2006.-6, N 1.-P. 87-97.

41. Nishitoh H., Matsuzawa A., Tobiume K., Saegusa K., Takeda K., Inoue K., Hori S., Kakizuka A., Ichijo H. ASK1 is essential for endoplasmic reticulum stress-induced neuronal cell death triggered by expanded polyglutamine repeats // Res. Paper.2002.-16, N11.-P. 1345-1355.

42. Takeda K., Hatai T., Hamazaki T. S., Nishitoh H., Saitoh M., Ichijo $H$. Apoptosis signal-regulating kinase 1 (ASK1) induces neuronal differentiation and survival of PC12 cells // J. Biol. Chem.-2000.-275, N 13.-P. 9805-9813.

43. Takeda K., Matsuzawa A., Nishitoh H., Tobiume K., Kishida S., Ninomiya-Tsuji J., Matsumoto K., Ichijo H. Involvement of ASK1 in $\mathrm{Ca}^{2+}$-induced p38 MAP kinase activation // EMBO Rep.-2004.-5, N 2.-P. 161-166.

44. Faigle R., Brederlau A., Elmi M., Arvidsson Y., Hamazaki T. $S$., Uramoto H., Funa $K$. ASK1 inhibits astroglial development via $\mathrm{p} 38$ mitogen-activated protein kinase and promotes neuronal differentiation in adult hippocampus-derived progenitor cells // Mol. and Cell. Biol.-2004.-24, N 1.-P. 280-293.

45. Kang J., Lemaire H. G., Unterbeck A., Salbaum J. M., Masters C. L., Grzeschik K. H., Multhaup G., Beyreuther K., Muller-Hill B. The precursor of Alzheimer's disease amyloid A4 protein resembles a cell-surface receptor // Nature.-1987.325, N 6106.-P. 733-736.

46. Heber S., Herms J., Gajic V., Hainfellner J., Aguzzi A., Ru-

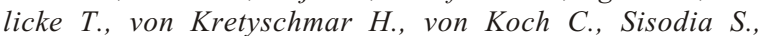
Tremml P., Lipp H. P., Wolfer D. P., Muller U. Mice with combined gene knock-outs reveal essential and partially redundant functions of amyloid precursor protein family members // J. Neurosci.-2000.-20, N 21.-P. 7951-7963.

47. Scheinfeld M. H., Roncarati R., Vito P., Lopez P. A., Abdallah M., D'Adamio $l$. Jun $\mathrm{NH}_{2}$-terminal kinase (JNK) interacting protein 1 (JIP1) binds the cytoplasmic domain of the Alzheimer's beta-amyloid precursor protein (APP) // J. Biol. Chem.-2002.-277, N 5.-P. 3767-3775.

48. Akterin S., Cowburn R. F., Miranda-Vizuete A., Jimenez A., Bogdanovic N., Winblad B., Cedazo-Minguez A. Involvement of glutaredoxin-1 and thioredoxin-1 in beta-amyloid toxicity and Alzheimer's disease // Cell Death Differ.-2006.-13, N 9.-P. 1454-1465.

49. Cataldi A., Rapino C., Bianchi G., Centurione L., Zingariello M., Di Giulio C., Antonucci A. Balance between hypertrophic and hypoxic stimulus in caspase-3 activation during rat heart development // J. Mol. Histol.-2005.-36, N 3.-P. 217-224.

50. Kashiwase K., Higuchi Y., Hirotani S., Yamaguchi O., Hikoso S., Takeda T., Watanabe T., Taniike M., Nakai A., Tsujimoto I., Matsumura Y., Ueno H., Nishida K., Hori M., Otsu K. CAMK2 activates ASK1 and NF-kappaB to induce cardiomyocyte hypertrophy // Biochem. and Biophys. Res. Communs.-2005.-327, N 1.-P. 136-142.

51. Higuchi Y., Otsu K., Nishida K., Hirotani S., Nakayama H., Yamaguchi O., Hikoso S., Kashiwase K., Takeda T., Watanabe T., Mano T., Matsumura Y., Ueno H., Hori M. The small GTP-binding protein Rac1 induces cardiac myocyte hypertrophy through the activation of apoptosis signalregulating kinase 1 and nuclear factor- $\mathrm{\kappa B} / / \mathrm{J}$. Biol. Chem.2003.-278, N 23.-P. 20770-20777.

52. Taniike M., Yamaguchi O., Tsujimoto I., Hikoso S., Takeda T., Nakai A., Omiya S., Mizote I., Nakano Y., Higuchi Y., Matsumura Y., Nishida K., Ichijo H., Hori M., Otsu K. Apoptosis signal-regulating kinase $1 /$ p38 signaling pathway negatively regulates physiological hypertrophy // Circulation.2008.-117, N 4.-P. 545-552.

53. Watanabe T., Otsu K., Takeda T., Yamaguchi O., Hikoso S., Kashiwase K., Higuchi Y., Taniike M., Nakai A., Matsumura Y., Nishida K., Ichijo H., Hori M. Apoptosis signal-regulating kinase 1 is involved not only in apoptosis but also in non-apoptotic cardiomyocyte death // Biochem. and Biophys. Res. Communs.-2005.-333, N 2.-P. 562-567.

54. Yokoi T., Fukuo K., Yasuda O., Hotta M., Miyazaki J., Takemura Y., Kawamoto H., Ichijo H., Ogihara T. Apoptosis signal-regulating kinase 1 mediates cellular senescence induced by high glucose in endothelial cells // Diabetes.-2006.55, N 5.-P. 1197-1204.

55. Imoto K., Kukidome D., Nishikawa T., Matsuhisa T., Sonoda K., Fujisawa K., Yano M., Motoshima H., Taguchi T., 
Tsuruzoe K., Matsumura T., Ichijo H., Araki E. Impact of mitochondrial reactive oxygen species and apoptosis signal-regulating kinase 1 on insulin signaling // Diabetes Res. Clin. Pract.-2007.-77.-P. 161-164.

56. Hao W., Takano T., Guillemette J., Papillon J., Ren G., Cybulsky $A$. V. Induction of apoptosis by the Ste20-like kinase SLK, a germinal center kinase that activates apoptosis signal- regulating kinase and p38 // J. Biol. Chem.-2006.-281, N 6.P. 3075-3084.

57. Song J. J., Lee Y. J. Role of the ASK1-SEK1-JNK1-HIPK1 signal in Daxx trafficking and ASK1 oligomerization // J. Biol. Chem.-2003.-278, N 47.-P. 47245-47252.

UDC 577.151.6 Received 15.05.08 